\title{
WORK LOCUS OF CONTROL AND DISPOSITIONAL OPTIMISM AS ANTECEDENTS TO JOB INSECURITY
}

\author{
J BOSMAN \\ J H BUITENDACH \\ bpkjb@puknet.ac.za \\ WorkWell: Research Unit for People, Policy \& Performance \\ North-West University, Vaal Triangle Campus \\ S. ROTHMAN \\ WorkWell: Research Unit for People, Policy \& Performance, North-West University
}

\begin{abstract}
The primary objective of this research was to investigate the relationship between job insecurity, work locus of control and dispositional optimism of employees working in two financial institutions $(\mathrm{N}=605)$. Results showed a practically significant relationship between job insecurity and work locus of control, implying that external locus of control was associated with higher levels of job insecurity. It was furthermore found that increased levels of dispositional optimism were associated with decreased levels of job insecurity. Both work locus of control and dispositional optimism held predictive value with regard to job insecurity whilst controlling for the impact of demographic variables.
\end{abstract}

\section{OPSOMMING}

Die hoofdoelwit met hierdie studie was om die verhouding tussen werksonsekerheid, werk lokus van beheer en disposisionele optimisme te ondersoek van werknemers werksaam binne twee finansiële instellings $(\mathrm{N}=605)$. ' $\mathrm{n}$ Dwarssneeopname-ontwerp is gebruik. Die resultate het aangetoon dat daar 'n prakties betekenisvolle verband bestaan tussen werk lokus van beheer en werksonsekerheid, wat beteken dat eksterne lokus van beheer geassosieer was met verhoogde vlakke van werksonsekerheid. Dit was verdermeer bevind dat verhoogde vlakke van disposisionele optimisme geassosieer was met laer vlakke van werksonsekerheid. Beide werk lokus van beheer and disposisionele optimisme het voorspellingswaarde met betrekking tot werksonsekerheid gehad terwyl die impak van demografiese veranderlikes gekontroleer is.

Internationally the changing world of work and its implications, as well as the demand on organisations for better performance and competitiveness is taking its toll on the emotional wellbeing of employees (De Witte, 1999). The result is large-scale workforce reductions, outsourcing, job insecurity and unemployment. Moses (1998) argues that the once valued social contract that guaranteed job security has been replaced by a reality that employees remain employed as long as they can make a contribution and their skills and knowledge are needed by the organisation. According to Moses (1998), the work rules have changed so much that workers have lost their sense of protection. In the past organisations provided a sense of security, allowing employees to belong to something bigger than themselves, as well as identification with people that are likeminded and working for a common purpose that instills pride and meaningfulness (Moses, 1998).

Job insecurity refers to employees' negative reactions to the changes concerning their jobs, as well as the fear that they may lose their jobs (De Witte, 1999, 2000; Davy, Kinicki \& Scheck, 1997). Job insecurity has also been described as the worry experienced by an individual in relation to the continuation of the present job (De Witte, 1999; Hartley et al., 1991; Sverke \& Hellgren, 2002; Rosenblatt \& Ruvio, 1996; Heaney, Israel \& House, 1994). Hui and Lee (2000) add that job insecurity encompasses the lack of control to maintain desired continuity in a threatened job situation.

In the literature job insecurity has been conceptualised from two points of view, i.e. as (i) global, or as a (ii) multidimensional concept (Mauno \& Kinnunen, 1999). In most instances, job insecurity has been defined according to the global viewpoint, signifying the threat of job loss or job discontinuity (Caplan, Cobb, French, Van Harrison \& Pinneau, 1980). Generally, this definition has been applied in the context of organisational crisis or change, in which job insecurity is considered as a first phase of the process of job loss (Ferrie, 1997; Joelson \& Wahlquist, 1987). From a global perspective, Van Vuuren (1990) emphasises that job insecurity has the following components:

Requests for copies should be addressed to: J Bosman, bpkjb@puk.ac.za
Firstly, it is a subjective experience or perception, as different employees might perceive the same situation differently. Secondly, job insecurity implies uncertainty regarding the future and finally, doubts about the continuation of the job as such, are central to job insecurity. In this research, use was made of De Witte's (2000) Job Insecurity Questionnaire (JIQ) as a measure of job insecurity, viewing job insecurity from a global, yet twodimensional perspective. De Witte (2000) developed the JIQ based on Borg's (1992) conceptualisation of job insecurity as a two-dimensional construct, consisting of an affective and cognitive component, where cognitive job insecurity relates to the perceived likelihood of job loss and affective job insecurity relates to fear of job loss.

The component of uncertainty inherent in job insecurity makes it a potent work stressor. It is argued that the lack of predictability or knowledge of what is to come in reference to the present job would give rise to distress in the individual. Several research studies have suggested that job insecurity should be related to different negative outcomes. These may be roughly categorised as attitudinal, health-related, and behavioural (Ashford et al., 1989; Dekker \& Schaufeli, 1995; Heaney et al., 1994; Hellgren \& Sverke, 2002; Hellgren, Sverke, Isaksson, 1999; Probst, 2000; Rosenblatt, Mohren, Sverke \& Hellgren, 2001; Sverke, Hellgren \& Näswall, 2002; Swaen, Van Amelsvoort, Talmud \& Ruvio, 1999).

The negative impact of job insecurity on the well-being of job incumbents, as well as the effect on organisational effectiveness necessitates research about job insecurity and the factors related to job insecurity (De Witte, 1999). De Witte (1999) and Burchell (1999) state that job insecurity has a significant negative influence on the emotional well-being of the individual. It reduces the level of job satisfaction and leads to psychosomatic complaints. Job insecurity has generally been considered a job stressor (Mauno \& Kinnunen, 1999). Prolonged job insecurity is more detrimental and acts as a chronic stressor whose negative effects become more potent as time goes by (Dekker \& Schaufeli, 1995). The harmful impact of job insecurity is clearly shown when two groups of people were compared in terms of 
knowledge of redundancy and the possibility of becoming redundant in the future. The group, who knew that redundancy was a reality, experienced improved psychological well-being in comparison with the group who was still uncertain. The unpredictability and the uncontrollability of job insecurity has a further negative impact on the psychological well-being of people (De Witte, 1999).

Job insecurity decreases commitment and impacts negatively on performance (Apisakkul, 2000; Ashford, Lee \& Bobko, 1989; Sverke \& Hellgren, 2002; Van Vuuren et al., 1991). Moses (1998) refers to workplace depression as a modern epidemic. The opposite of depression is excitement, anticipation, and joy, which is lacking in today's organisations. Greenhalgh and Sutton (1991) found that job insecurity inhibits change readiness because of fear of the future. It also holds negative consequences for industrial relations because of mistrust, blame, and general dissatisfaction (Greenhalgh \& Sutton, 1991). Job insecurity weakens the quality of human relations and perceived efficacy in the organisation (Kinnunen et al., 2000).

Van Vuuren, Klandermans, Jacobson and Hartley (1991) found that aspects like safeguards (protection from possible job loss), age, and the fact that job security is controlled externally, can increase job insecurity. Also, the more the job features that are endangered, the higher the job insecurity. Qualifications (Frese, 1985; Hellgren \& Sverke, 2003), financial security (Kinnunen \& Nätti, 1999) and employability of employees (Fugate \& Ashforth, 2003; Gallie, White, Cheng \& Tomlinson, 1998; Sverke \& Hellgren, 2002) also influence the experience of job insecurity.

A large proportion of the job insecurity research focuses mainly on the consequences on job insecurity and some research focusing on antecedents of job insecurity can also be found in the literature. Limited research has however been conducted focusing on personality traits as antecedents to job insecurity. Personality dispositions have the ability to affect an individual's interpretation of a situation, and therefore information regarding the relationship between job insecurity and personality is essential.

Work locus of control is described as the perception that individuals have of the relationship between their own behaviour and the results of reward or punishment. Individuals with an internal locus of control believe that they can influence the results of their actions, whereas individuals with an external locus of control believe that the results of their actions are controlled by forces outside of themselves (Pretorius \& Rothmann, 2001). From the literature, it is evident that the locus of control construct is based on the cause and consequence relationship and therefore future expectations (for example, anticipation of redundancy) can be construed in terms of current behaviour. A large amount of research comparing internals with externals has consistently shown that individuals who have high scores in externality are less satisfied with their jobs, have higher absenteeism rates, are more alienated from the work setting, and are less involved in their jobs than are internals (Robbins, 2001). Spector (1988) postulates that workers with an internal locus of control will perform better in the work situation since they have more trust in their own abilities as well as the possible rewards.

With regard to job insecurity and locus of control, Salter (1999) found a positive correlation between job security and internal locus of control, where internal control was associated with higher levels of job security (lower job insecurity). As noted, individuals with a strong internal orientation believe that they can influence the work environments, whereas individuals with a strong external orientation believe that events are controlled by factors beyond their control. Consequently, one would expect that an individual with an external orientation will perceive that their jobs are more threatened than a person with an internal orientation. Hence the following hypotheses are proposed.

$\mathrm{H}_{1}$ : Higher levels of internal work locus of control are practically significantly associated with lower levels of job insecurity.

$\mathrm{H}_{2}$ : Work locus of control holds predictive value with regard to job insecurity.

Scheier and Carver (1985) define dispositional optimism as a general expectation of experiences throughout one's life. Dispositional optimism can be defined as a person's positive outlook towards life events (Ebert, Tucker \& Roth, 2002; Scheier, Carver \& Bridges, 1994). Optimists believe that good outcomes will occur in life and can therefore appraise stressful events more positively and mobilise their resources to take direct action in response to a stressor. Optimism has been identified as an important factor in physical health, especially for people experiencing stress (Cassidy, 2000). In a hierarchical multiple regression analysis done by Fry (1995), evidence was found that optimism significantly moderates the relationship between daily hassles and self-esteem maintenance, burnout and physical illness. A number of researchers described this personality trait as a psychological resistance factor, which could be used to conceptualise individual differences and are related to more positive outcomes (Ebert et al., 2002). Positive outcomes being predicted by optimism include - coping with major life stresses; adjusting to major life transitions; and more positive responses to minor stresses (Hasan \& Power, 2002). Wrosch and Scheier (2003) indicate that as opposed to the attributional approach to optimism, dispositional optimism does not differentiate the basis of the expectation, i.e. not establishing whether a person would for example hold positive expectations for the future because they are efficacious or because they are lucky. From the dispositional optimism perspective it is merely important to establish whether a person thinks that good outcomes will occur. Dispositional optimism would thus be expected to affect an individual's job insecurity perceptions, with a more optimistic individual displaying a lower probability to perceive job insecurity, than a person measuring low on this trait. Hence, the following hypotheses are proposed.

$\mathrm{H}_{3}$ : Higher levels of dispositional optimism are practically significantly associated with lower levels of job insecurity.

$\mathbf{H}_{4}$ : Dispositional optimism holds predictive value with regard to job insecurity.

Based upon the above literature review, the general objective of this research is to investigate the relationship between job insecurity, work locus of control and dispositional optimism. This research is of significance as although a large amount of research has been done on the consequences of job insecurity, limited research has been done on the antecedents of job insecurity. Research on the relationship between demographic variables and job insecurity can be found, but a need for research relating personality variables to job insecurity exists. The research was undertaken at two large financial institutions in South Africa, both of which had been subjected to restructuring and change efforts in the recent past.

\section{RESEARCH DESIGN}

\section{Research approach}

A cross-sectional survey design was utilised to describe the information on the population collected at that time. Crosssectional designs are used to examine groups of subjects at various stages of development simultaneously, while the survey describes a technique of data collection in which questionnaires 
are used to gather data about an identified population (Burns \& Grove, 1993). This design is well-suited to the descriptive and predictive functions associated with correlational research, whereby relationships between variables are examined (Shaughnessy \& Zechmeister, 1997).

\section{Participants}

This study was undertaken within two financial institutions in Gauteng. A stratified, random sample was taken from various job levels within two financial institutions. A total population of about $1000 \quad(\mathrm{~N}=1000)$ employees were targeted. From this population of 1000 , a response rate of $28,6 \%(\mathrm{~N}=146)$ was achieved for the one organisation, and $91,8 \%(\mathrm{~N}=459)$ for the other, resulting in a total population of 603 participants. Table 1 provides an indication of the demographic characteristics of the research group.

TABLE 1

Characteristics of THe Participants $(\mathrm{N}=603)$

\begin{tabular}{llrc}
\hline Item & Category & Frequency & Percentage \\
\hline Gender & Male & 309 & 51,2 \\
& Female & 288 & 47,8 \\
& Missing & 6 & 1,0 \\
Age & 24 years and younger & 11 & 1,8 \\
& 25-35 years & 169 & 28,0 \\
& 36-45 years & 223 & 37,0 \\
& 46-55 years & 151 & 25,0 \\
& 56 years and older & 44 & 7,3 \\
Race & Missing & 5 & 0,8 \\
& Black & 115 & 19,1 \\
& White & 462 & 76,6 \\
& Missing & 6 & 4,3 \\
Qualifications & St. 8-10 & 272 & 45,1 \\
& Degree/Diploma & 324 & 53,7 \\
& Missing & 7 & 1,2 \\
\hline
\end{tabular}

Although the study population appeared to be representative in terms of gender, as well as age and qualification, it was highly misbalanced in terms of race, with almost $77 \%$ of the population falling within the "white" category and only $19 \%$ being representative of the "black" category.

\section{Measuring instruments}

Three questionnaires as used in the empirical study, namely the Job Insecurity Questionnaire (JIQ), The Work Locus of Control Scale (WLOC) and the Life Orientation Test-Revised (LOT-R) Questionnaire.

The Job Insecurity Questionnaire (JIQ) is 11-item questionnaire which was used to measure the job insecurity of the participants. The items of the JIQ measuring global job insecurity are reported to have a Cronbach alpha coefficient of 0,92 (De Witte, 2000). The questionnaire focuses on two aspects, namely the cognitive comprehension of the possibility of job loss, as well as the affective reaction to the feelings of job insecurity (De Witte, 2000). Both scales have been shown to be highly reliable, with the six items measuring cognitive job insecurity, displaying a Cronbach alpha coefficient of 0,90 ; and the five items of affective job insecurity having a Cronbach alpha coefficient of 0,85 (De Witte, 2000). In South African research, Cronbach alpha coefficients for the total scale have been found to vary between 0,81 and 0,84 (Elbert, 2003; Heymans, 2002; Human, 2002).

The Work Locus of Control Scale (WLOC) consists of 16 items and is used to measure the participants' locus of control within the work environment. The original number of items included in the scale was 49-these items were developed from the conceptual analyses of the construct work locus of control. Three criteria were used in the item selection namely: total correlation, lack of correlation with social desirability and the scale had to conform to equal amounts of internally and externally formulated items. The item total correlations vary from 0,24 to 0,67 , with a low inter-item correlation of 0,25 (O'Brien, 1983; Spector, 1982). In order to be consistent with Rotter's Internal-External-scale, the low scores represent internal locus of control on the scale. Spector (1988) found alpha coefficients for the WLOC varying between 0,75 and 0,85 . Spector (1988) found evidence for the construct validity of the WLOC.

The Life Orientation Test-Revised (LOT-R), which is a ten item measure was used to measure dispositional optimism (Scheier et al., 1994). Six items contribute to the optimism score and four items are fillers. The LOT-R is measured on a five-point Likert Scale, ranging from 5 (I strongly agree) to 1 (I strongly disagree). The LOT-R was found to have adequate internal consistency (Cronbach's alpha $=0,78)$ and excellent convergent and discriminant validity (Scheier et al., 1994). Based on a sample of 204 college students, Harju and Bolen (1998) obtained a Cronbach alpha coefficient of 0,75 .

\section{Analysis of data}

The data analysis was carried out with the help of the SPSSprogram (SPSS Inc, 2003). Statistical analysis regarding reliability and validity of the measuring instruments, descriptive statistics, correlation coefficients, and multiple regression analyses were conducted. Cronbach alpha coefficients, inter-item correlation coefficients and factor analysis was used to assess the reliability and validity of the measuring instruments (Clark \& Watson, 1995). Descriptive statistics were used to analyse the data. A cut-off point of $p \leq$ 0,05 was set for the statistical significance of the results. Effect sizes (Cohen, 1988) was used to decide on the practical significance of the findings. Pearson product-moment correlation coefficients were used to specify the relationships between the variables. A cut-off point of 0,30 (medium effect, Cohen, 1988) was set for the practical significance of correlation coefficients. Multiple regression analyses, controlling for background variables were used to determine whether work locus of control and dispositional optimism held any predictive value with regard to job insecurity.

\section{RESULTS}

\section{Interpretation}

A simple principal component analysis was conducted on the 11 items of the JIQ on the total sample of employees at two financial institutions in Gauteng. Based on analysis of the eigenvalues (larger than 1) and scree plot, it was indicated that two factors could be extracted, which is consistent with the findings of De Witte (1997). Next, principal component analysis with a direct Oblimin rotation was used in carrying out factor analysis.

As indicated in Table 2, items 1 to 4 loaded on one factor, with the remaining items loading on the other factor, with item 10 loading rather heavily on both factors. Theoretically, items 1, 2, 3, 4, 10 and 11 are representative of the cognitive job insecurity scale, whereas items $5,6,7,8$, and 9 are representative of the affective scale. Furthermore, upon scrutinising the individual item loadings, it appeared that what had emerged were not two scales being representative of cognitive and affective job insecurity as expected, but rather Factor 1 as being representative of job insecurity (all negatively phrased items) and Factor 2 as comprising of all positively phrased items (despite items 1 to 4 having been 
reversed). Item 10, "There is a possibility that I might lose my job in the near future", probably loaded on both factors due to the fact that it can be interpreted in either a positive or negative manner, i.e. "there is a chance, but it is only a possibility" or "there is a chance, irrespective of how strong". Nevertheless, item 10 did load more strongly on Factor 1. Accordingly, the two related factors $(r=0,55)$ were thus labelled "job insecurity" and "job security" and only the items respresenting "job insecurity" were used in subsequent analyses.

TABLE 2

Pattern matrix of The 11 items JIQ for employees of two FINANCIAL INSTITUTIONS IN GAUTENG $(\mathbf{N}=\mathbf{6 0 3})$

\begin{tabular}{lccc}
\hline ITEM & \multicolumn{2}{c}{ Component } \\
\hline & & 2 \\
1. I think that I will be able continue working here & $-0,10$ & $\mathbf{0 , 9 3}$ \\
2. There is only a small chance that I will become & 0,08 & $\mathbf{0 , 5 8}$ \\
unemployed. & & \\
3. I am certain/sure of my job environment. & $-0,12$ & $\mathbf{0 , 8 2}$ \\
4. I am very sure that I will be able to keep my job. & 0,94 \\
5. It makes me anxious that I might become unemployed. & 0,85 & $-0,14$ \\
6. I feel uncertain about the future of my job. & $\mathbf{0 , 7 0}$ & 0,24 \\
7. I worry about the continuation of my career. & 0,85 & 0,07 \\
8. I fear that I might lose my job. & 0,82 & 0,16 \\
9. I fear that I might get fired. & 0,89 & $-0,13$ \\
10. There is a possibility that I might lose my job in the & 0,52 & 0,43 \\
$\quad$ near future. & & 0,65 & 0,12
\end{tabular}

A simple principal component analysis was conducted on the 16 items of the WLOC on the total sample of employees in two financial institutions in Gauteng. Two factors could be extracted based on analysis of eigenvalues (larger than 1) and scree plot. An oblique rotation showed that factors were not strongly correlated and thus a principal factor analysis with varimax rotation was used.

Upon inspection of Table 3 it is apparent that all the items relating to external locus of control load on the first factors, whereas the remaining internal locus of control items load on the second factor. Theoretically, the work locus of control construct runs on a continuum. One would expect to obtain two factors being representative of the opposite poles of the continuum, but would score it on one scale. In the tradition of the Rotter I-E scale, the lower end of the continuum represents internal locus of control, whereas the higher end represents external locus of control (Spector, 1988).

With reference to the LOT-R Questionnaire a simple principal component analysis was conducted on the 6 items (10 minus 4 filler items) of the questionnaire on the total sample of employees in two financial institutions in Gauteng. One factor, with all items loading appropriately was extracted, the results of which are detailed in Table 4.

Table 5 details descriptive statistics of the measuring instruments used in this research. With regard to skewness and kurtosis, the values must ideally be as close as possible to zero. The values obtained for skewness and kurtosis of all measuring instruments are indicative of normal distribution. The Cronbach alpha coefficients of the JIQ, the WLCS and the
LOT-R are considered to be acceptable, compared to the guideline of a á $=0,70$ (Nunnally \& Bernstein, 1994). Furthermore, the inter-item correlations for the WLCS and LOT-R are considered acceptable compared to the guideline of $0,15=r=0,50$ (Clark \& Watson, 1995), although the inter-item correlation of the JIQ fell slightly above the 0,50 cut-off point, but was not high enough to suggest a significant irregularity.

TABLE 3

ROTATED COMPONENT MATRIX OF THE 16 ITEMS OF THE WLOC-QUESTIONNAIRE FOR EMPLOYEES OF TWO FINACIAL INSTITUTIONS IN GAUTENG $(\mathrm{N}=\mathbf{6 0 3})$

\begin{tabular}{|c|c|c|}
\hline \multirow[t]{2}{*}{ ITEM } & \multicolumn{2}{|c|}{ Component } \\
\hline & 1 & 2 \\
\hline 1. A job is what you make of it. & $-0,03$ & 0,76 \\
\hline $\begin{array}{l}\text { 2. On most jobs, people can pretty much accomplish } \\
\text { whatever they set out to accomplish. }\end{array}$ & 0,09 & 0,66 \\
\hline $\begin{array}{l}\text { 3. If you know what you want out of a job, you can find } \\
\text { a job that gives it to you. }\end{array}$ & 0,13 & 0,71 \\
\hline $\begin{array}{l}\text { 4. If employees are unhappy with decisions made by their } \\
\text { boss, they should do something about it. }\end{array}$ & $-0,04$ & 0,71 \\
\hline 5. Getting the job you want is mostly a matter of luck & 0,73 & 0,02 \\
\hline 6. Making money is primarily a matter of good fortune & 0,74 & $-0,09$ \\
\hline $\begin{array}{l}\text { 7. Most people are capable of doing their jobs well if they } \\
\text { make the effort. }\end{array}$ & $-0,11$ & 0,72 \\
\hline $\begin{array}{l}\text { 8. In order to get a really good job, you need to have } \\
\text { family members or friends in high places. }\end{array}$ & 0,78 & 0,13 \\
\hline 9. Promotions are usually a matter of good fortune & 0,81 & 0,11 \\
\hline $\begin{array}{l}\text { 10. When it comes to getting a really good job, who you } \\
\text { know is more important than what you know. }\end{array}$ & 0,80 & 0,06 \\
\hline $\begin{array}{l}\text { 11. Promotions are given to employees who perform well } \\
\text { on their job. }\end{array}$ & 0,14 & 0,66 \\
\hline $\begin{array}{l}\text { 12. To make a lot of money you have to know the } \\
\text { right people. }\end{array}$ & 0,69 & $-0,18$ \\
\hline $\begin{array}{l}\text { 13. It takes a lot of luck to be an outstanding employee on } \\
\text { most jobs. }\end{array}$ & 0,70 & 0,03 \\
\hline $\begin{array}{l}\text { 14. People who perform their jobs well generally get } \\
\text { rewarded for it. }\end{array}$ & 0,21 & 0,71 \\
\hline $\begin{array}{l}\text { 15. Most employees have more influence on their } \\
\text { supervisors than they think they do. }\end{array}$ & $-0,12$ & 0,42 \\
\hline $\begin{array}{l}\text { 16. The main difference between people who make a lot of } \\
\text { money and people who make a little money is luck. }\end{array}$ & 0,73 & 0,12 \\
\hline
\end{tabular}

TABLE 4

COMPONENT MATRIX OF THE 6 ITEMS OF THE LOT-R QUESTIONNAIRE FOR EMPLOYEES IN TWO FINANCIAL INSTITUTIONS IN GAUTeng $(\mathbf{N}=603)$

ITEM Component

1. In uncertain times, I usually expect the best 0,51

3. If something can go wrong for me, it will

4. I'm always optimistic about my future 0,65

7. I hardly ever expect things to go my way 0,63

9. I rarely count on good things happening to me 0,74

10. Overall, I expect more good things to happen to me than bad 0,63 
Pearson correlations were used to determine the degree to which one variable is related to another. The Correlation Coefficients between the various constructs measured in this research are indicated in Table 6 . As indicated by Table 6 , a positive correlation of medium effect was obtained between work locus of control and job insecurity, suggesting that external locus of control (the higher end of the continuum) is associated with increased levels of job insecurity and internal locus of control is associated with lower levels of job insecurity. A negative correlation of medium effect was obtained between dispositional optimism and job insecurity, suggesting that higher levels of dispositional optimism is associated with lower levels of job insecurity and vice versa.

TABLE 5

Descriptive statistics, Cronbach Alpha coefficients AND INTER-ITEM CORRELATION COEFFICIENTS OF THE MEASURING INSTRUMENTS FOR EMPLOYEES WORKING IN TWO FINANCIAL INSTITUTIONS IN GAUTENG

\begin{tabular}{lcccccc}
\hline Test and subscales & Mean & SD & Skewness & Kurtosis & Inter-item r & $\alpha$ \\
\hline JIQ & 3,00 & 1,13 & 0,27 & $-0,61$ & 0,61 & 0,92 \\
WLCS & 2,69 & 0,69 & 0,25 & $-0,14$ & 0,23 & 0,82 \\
LOT-R & 2,69 & 0,69 & 0,25 & $-0,14$ & 0,28 & 0,70 \\
\hline
\end{tabular}

TABLE 6

CORRELATION COEFFICIENTS BETWEEN THE JIQ, WLOC AND LOT-R

\begin{tabular}{lccc}
\hline 1 & 2 & 3 \\
\hline 1. JIQ & - & - & - \\
2. WLCS & $0,39 * \dagger$ & - & - \\
3. LOT-R & $-0,42 * \dagger$ & $-0,41 * \dagger$ & - \\
\hline
\end{tabular}

*Statistically significant correlation

+ Correlation is practically significant $r=0,30$ (medium effect)

++ Correlation is practically significant $r=0,50$ (large effect)

Regression Analyses was used to further examine the relationship between variables (Wisniewski, 1997). According to Cohen (1993) a correlation (R) can only be better understood by determining its square $\left(\mathrm{R}^{2}\right)$. A regression analysis is used to determine the proportion of the total variance of one variable that is explained by another variable (Moore, 1995). The multiple regression analyses were conducted with work locus of control and dispositional optimism as independent variables, also controlling for the effects of age, gender, qualifications and race, and with job insecurity as dependent variable.

The regression analysis reflected in Table 7 indicates that the demographic variables (particularly race) contributed toward $4 \%$ of the variance in job insecurity A R-value of 0,21 was obtained, which falls below the practical significance cut-off point. Upon inclusion of work locus of control, the adjusted $\mathrm{R}^{2}$ increased by $13 \%$.

The regression analysis indicated in Table 8 indicates that the demographic variables (mostly race) predicted $4 \%$ of the variance in job insecurity. A R-value of 0,21 was obtained. The adjusted $\mathrm{R}^{2}$ increased by $14 \%$ when dispositional optimism was included. A practically significant R-value of medium effect $(0,44)$ was obtained.

TABLE 7

REgRESSION ANALYSIS - WORK LOCUS OF CONTROL AND DEMOGRAPHIC VARIABLES: JOB INSECURITY

\begin{tabular}{|c|c|c|c|c|c|c|}
\hline \multicolumn{7}{|c|}{ ANALYSIS OF VARIANCE } \\
\hline \multicolumn{7}{|c|}{ Model 1: Demographic variables } \\
\hline \multirow{5}{*}{$\begin{array}{l}\text { R: } 0,21 \\
\mathrm{R}^{2}: 0,04 \\
\text { Adjusted } \mathrm{R}^{2}: 0,04 \\
\text { Standard Error: } 1,10\end{array}$} & \multicolumn{3}{|c|}{ Source of variation } & df & $\begin{array}{l}\text { Sum of } \\
\text { squares }\end{array}$ & $\begin{array}{c}\text { Mean } \\
\text { Square }\end{array}$ \\
\hline & \multirow{4}{*}{\multicolumn{3}{|c|}{$\begin{array}{l}\text { Regression } \\
\text { Residual } \\
F=6,26 \quad p=0,000\end{array}$}} & 1 & 30,12 & 7,53 \\
\hline & & & & & & \\
\hline & & & & & & \\
\hline & & & & 543 & 653,01 & 1,20 \\
\hline \multicolumn{7}{|c|}{ Model 2: Dmographic variables and work locus of control } \\
\hline \multirow{5}{*}{$\begin{array}{l}\text { R: } 0,42 \\
\mathrm{R}^{2}: 0,18 \\
\text { Adjusted } \mathrm{R}^{2}: 0,17 \\
\text { Standard Error: } 1,02\end{array}$} & \multicolumn{3}{|c|}{ Source of variation } & df & Sum of & $\begin{array}{c}\text { Mean } \\
\text { Square }\end{array}$ \\
\hline & \multirow{4}{*}{\multicolumn{3}{|c|}{$\begin{array}{l}\text { Regression } \\
\text { Residual } \\
F=23,71 \quad p=0,000\end{array}$}} & 5 & 122,59 & 24,52 \\
\hline & & & & & & \\
\hline & & & & & & \\
\hline & & & & 542 & 560,54 & 1,03 \\
\hline \multicolumn{7}{|c|}{ VARIABLES IN THE EQUATION } \\
\hline INDEPENDENT VARIA & LES & B & SEB & Beta & $\mathrm{t}$ & $\mathbf{P}$ \\
\hline Gender & & 0,18 & 0,10 & 0,08 & 1,84 & 0,066 \\
\hline Race & & 0,47 & 0,12 & 0,17 & 3,86 & 0,000 * \\
\hline Age & & $-0,09$ & 0,05 & $-0,08$ & $-1,79$ & 0,074 \\
\hline Qualifications & & $-0,07$ & 0,10 & $-0,03$ & $-0,76$ & 0,449 \\
\hline Gender & & 0,07 & 0,09 & 0,03 & 0,72 & 0,471 \\
\hline Race & & 0,41 & 0,11 & 0,153 & 3,65 & 0,000 * \\
\hline Age & & $-0,04$ & 0,05 & $-0,03$ & $-0,81$ & 0,418 \\
\hline Qualifications & & $-0,07$ & 0,09 & $-0,03$ & $-0,75$ & 0,453 \\
\hline Work locus of control & & 0,61 & 0,07 & 0,38 & 9,46 & $0,000^{*}$ \\
\hline
\end{tabular}

${ }^{*} \mathrm{p}<0,05$

TABLE 8

REgRESSION ANALYSIS - DISPOSITIONAL OPTIMISM AND DEMOGRAPHIC VARIABLES: JOB INSECURITY

\begin{tabular}{llccc}
\hline \multicolumn{4}{c}{ ANALYSIS OF VARIANCE } \\
\hline & Model 1: Demographic variables & \\
\hline R: 0,21 & Source of variation & df & Sum of & Mean \\
R $: 0,04$ & & squares & Square \\
Adjusted R $2: 0,04$ & & & \\
Standard Error: 1,10 & Regression & 4 & 29,811 & 7,453 \\
& $\begin{array}{l}\text { Residual } \\
\text { F }=6,18 \mathrm{p}=0,000\end{array}$ & 546 & 658,260 & 1,206 \\
& & & & \\
\hline
\end{tabular}

Model 2: Demographic variables and dispositional optimism

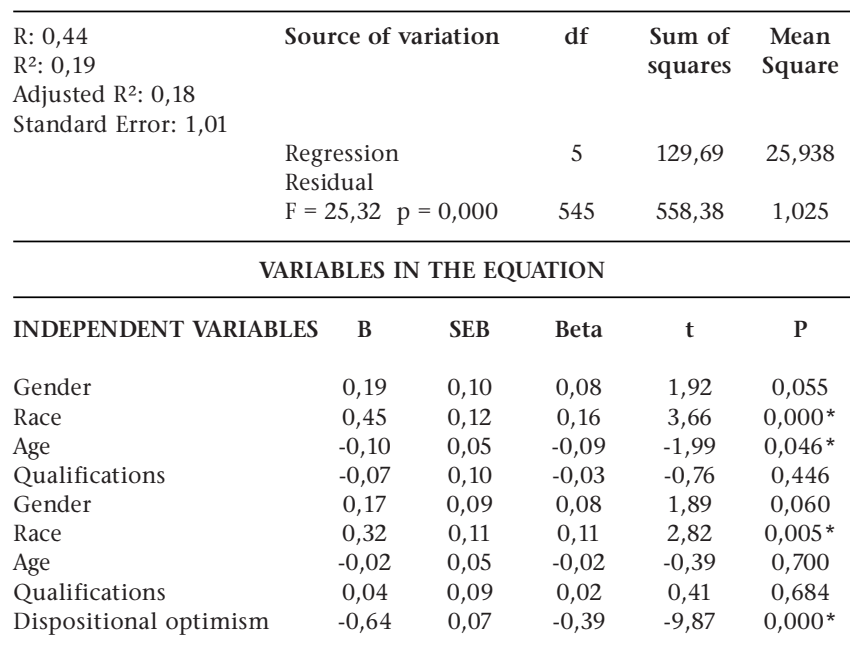




\section{DISCUSSION}

\section{Interpretation}

The general objective of this research was to determine the relationships between job insecurity, work locus of control and dispositional optimism.

A practically significant relationship of medium effect was obtained between job insecurity and work locus of control, suggesting that external work locus of control is associated with increased levels of job insecurity, whereas internal work locus of control is associated with decreased levels of job insecurity. This finding lends support to hypothesis 1, which stated that a practically significant relationship exists between work locus of control and job insecurity. Furthermore, a regression analysis indicated that work locus of control predicted $13 \%$ of the variance in job insecurity (when controlling for the impact of the demographic variables), which lends support to hypothesis 2 .

It was also established that a negative practically significant relationship of medium effect exists between dispositional optimism and job insecurity. Individuals with higher levels of dispositional optimism will tend to experience lower levels of job insecurity than individuals with lower levels of dispositional optimism. Regression analysis indicated that dispositional optimism predicted $14 \%$ of the variance in job insecurity when controlling for the impact of the demographic variables. These results lend support to both hypothese 3 and 4 . Race was also found to hold some predictive value with regard to job insecurity levels.

\section{Conclusions}

From the above results it can be concluded that although the JIQ presented with good reliability, some further refinement of the measure may be required. Although the JIQ presented with a twofactor structure as expected, these factors were not representative of affective and cognitive job insecurity, but rather of a job security and a job insecurity scale. This is related to the positive and negative phrasing of the items, hence rephrasing of the items may be necessary. The WLOC and LOT-R presented with adequate reliability levels and factorial structures. It was hypothesised that individuals with an external locus of control will appraise their work situations as being more threatened as compared to individuals with an internal locus of control, given that externals do not believe that they can control work environment features. The results of this study supported this hypothesis indicating that work locus of control holds predictive value with regard to job insecurity. It can thus be concluded that individuals leaning toward an internal work locus of control will tend to experience lower levels of job insecurity than individuals with an external work locus of control.

It was furthermore hypothesised that individuals measuring high on dispositional optimism would appraise their jobs to be less insecure than individuals measuring low on dispositional optimism, primarily because optimists believe that good outcomes will occur in life. The research findings lent support to this notion and it was found that dispositional optimism holds predictive value with regard to job insecurity. It can therefore be concluded that individuals with high levels of dispositional optimism experience lower levels of job insecurity. The implications of these findings are significant, not only because individuals measuring high on dispositional optimism and internal work locus of control will display a lower probability to perceive job insecurity, but also because only would expect them to suffer less of numerous negative consequences related to job insecurity, related to their lower levels of job insecurity.

\section{Limitations and recommendations}

The generalisability of this research is limited due to the fact that it was only conducted in two financial institutions. Therefore, the relationship between job insecurity, work locus of control and dispositional optimism must be investigated in other contexts and industries as well. Furthermore, the research sample mainly consisted of white employees and other cultures were not sufficiently represented in the sample. Stratified random sampling might have delivered a more balanced study population. Causal inferences cannot be made, a shortcoming that can be addressed by making use of longitudinal designs. Future research should also focus on other personality variables in relation to job insecurity, for example examining traits such as sense of coherence, selfefficacy, hope and happiness as antecedents to job insecurity or as moderators in the relationship between job insecurity and various outcomes.

\section{REFERENCES}

Apisakkul, A. (2000). A study of white collar workers in Thailand. Humanities and Social Sciences, 60 (11A), 4081 Abstract from: Eric File: Psych INFO Item: 0419-4209.

Ashford, S., Lee. C. \& Bobko, P. (1989). Content, causes and consequences of job insecurity: A theory-based measure and substantive test. Academy of Management Journal, 32 (4), 803-829.

Borg, I. (1992). Reflections and investigations in the measurement of subjective uncertainty in the work environment. Zeitschrift für Arbeits- und Organisationspsychologie, 36 (3), 107-116.

Borg, I. \& Elizur, D. (1992). Job insecurity: Correlates, moderators and measurement. International Journal of Manpower, 12, 253-259.

Burchell, B. J. (1999). The unequal distribution of job insecurity. International Review of Applied Economics, 13, 437-459.

Burns, N. \& Grove, S. K. (1993). The practice of nursing research: Conduct, critique, and utilization (2nd ed.). Philadelphia, PA: W. B. Saunders.

Caplan, R. D., Cobb, S., French, J. R. P., van Harrison, R. V. \& Pinneau, S. R. (1980). Job demands and worker health: Main effects and occupational differences. Ann Arbor, MI: Survey Research Centre, Institute of Social Research, University of Michigan.

Cassidy, T. (2000). Social background, achievement motivation, optimism and health: A longitudinal study. Counselling Psychology Quarterly, 13, 399-413.

Clark, L. A. \& Watson, D. (1995). Constructing validity: Basic issues in objective scale development. Psychological Assessment, 7, 309-319.

Cohen, J. (1988). Statistical power analysis for the behavioural sciences (2nd ed). Hillsdale, NJ: Lawrence Erlbaum \& Associates.

Cohen, A. (1993). Work commitment in relation to withdrawal intentions and union effectiveness. Journal of Business Research, 26, 75-90.

Davy, J. A., Kinicki, A. J. \& Scheck, C.L. (1997). A test of job insecurity's direct and mediated effects on withdrawal cognitions. Journal of Organizational Behavior, 18, 323-349.

Dekker, S. W. A. \& Schaufeli, W. B. (1995). The effects of job insecurity on psychological health and withdrawal: A longitudinal study. Australian Psychologist, 30, 57-63.

De Witte, H. (1997, April). Long term job insecurity as a stressor: Its impact on satisfaction and commitment. Paper delivered at the 8th European Congress on Work and Organisational Psychology, Verona.

De Witte, H. (1999). Job insecurity and psychological well-being: Review of the literature and exploration of some unresolved issues. European Journal of Work and Organizational Psychology, 8 (2), 155-177.

De Witte, H. (2000). Arbeidsethos en jobonzekerheid: meting en gevolgen voor welzijn, tevredenheid en inzet op het werk.

Dekker, S. W. A. \& Schaufeli, W. B. (1995). The effects of job insecurity on psychological health and withdrawal: A longitudinal study. Australian Psychologist. 30: 57-63. 
Ebert, S. A., Tucker, D. C. \& Roth, D. L. (2002). Psychological resistance factors as predictors of general health status and physical symptoms reporting. Psychology, Health \& Medicine, 7, 363-375.

Elbert, J. (2003). Job insecurity and psychological strengths of service workers in a parastatal. Unpublished master's dissertation, Vaal Triangle Campus of the Potchefstroom University, Vanderbijlpark.

Ferrie, J. E. (1997). Labour market status, insecurity and health. Journal of Health Psychology, 2, $155-170$.

Frese, M. (1985). Stress at work and psychosomatic complaints: A causal interpretation. Journal of Applied Psychology, 70, 314-328.

Greenhalgh, L. \& Sutton, R. (1991). Mapping the context. In J. Harley, D. Jackson, B. Klandermans \& T. van Vuuren. Job insecurity: Coping with jobs at risk. London: Sage Publications.

Fry, P.S. (1995). Perfectionism, humor, and optimism as moderators of health outcomes and determinants of coping styles of women executives. Genetic, Social \& General Psychology Monographs, 121, 213-246.

Harju, B. \& Bolen, L. M. (1998). The effects of optimism on coping and perceived quality of life of college students. Journal of Social Behavior \& Personality, 13, 185-200.

Hartley, J., Jacobson, D., Klandermans, B. \& Van Vuuren, T. (1991). Job insecurity coping with jobs at risk. London: SAGE Publications, Ltd.

Hasan, N. \& Power, T. G. (2002). Optimism and pessimism in children: A study of parenting correlates. International Journal of Behaviour Development, 26, 185-191.

Heaney, C. A., Israel, B. A. \& House, J. S. (1994). Chronic job insecurity among automobile workers: Effects on job satisfaction and health. Social Science \& Medicine, 38, 1431-1437.

Hellgren, J. \& Sverke, M. (2002). Does job insecurity lead to impaired well-being or visaversa? Estimation of cross- lagged effects using latent variable modelling. Journal of Organisational Behaviour, 2, 215-222.

Hellgren, J., Sverke, M. \& Isaksson, K. (1999). A two-dimensional approach to job insecurity: Consequences for employee attitudes and well-being. European Journal of Work and Organizational Psychology, 8, 179-195.

Heymans, D. R. (2002). The relationship between job insecurity, job satisfaction and organisational commitment of maintenance workers in parastatal. Unpublished master's dissertation, P U for CHE, Vanderbijlpark.

Hui, C. \& Lee, C. (2000), Moderating effects of organizationalbased self-esteem on satisfaction, career aspirations and stress levels of employees. Journal of Industrial Psychology, 22 (3), 1-6.

Human, I. J. (2002). Die verhouding tussen werksonsekerheid, koherensiesin, lokus van beheer en selfdoeltreffendheid by menslike hulpbron werknemers in 'n finansiële instelling. Unpublished master's dissertation, Vaal Triangle Campus of the Potchefstroom University, Vanderbijlpark.

Joelson, M. \& Wahlquist, L. (1987). The psychological meaning of job insecurity and job loss: The results of a longitudinal study. Social Science and Medicine, 25, 179-182.

Kinnunen, U., Mauno, S., Nätti, J. \& Happonen, M. (2000). Organisational antecedents and outcome of job insecurity: A longitudinal study in three organisations in Finland. Journal of organisational behavior, 21, 443-459.
Mauno, S. \& Kinnunen, U. (1999). Job insecurity and well-being: a longitudinal study among male and female employees in Finland. Community, Work \& Family, 2, 147-171.

Mohren, D. C. L., Swaen, G. M. H., van Amelsvoort, L. G. P. M., Borm, P. J. A. \& Galama, J. M. D. (2003). Job insecurity as a risk factor for common infections and health complaints. Journal of Occupational and Environmental Medicine, 45, 123-127, Feb.

Moses, B. (1998). Career intelligence. San Francisco, CA: BerrettKoehler Publishers.

Nunnally, J. C. \& Bernstein, I. H. (1994). Psychometric theory (3rd ed.). New York: McGraw-Hill.

O'Brien, G.E. (1983). Locus of control, work and retirement. In H.M. Lefcourt (Eds.), Research in Locus of Control (pp. 1250-1257). New York: Academic Press.

Pretorius, M. \& Rothmann, S. (2001). Die verband tussen koherensiesin, lokus van beheer, selfdoeltreffendheid en werkstevredenheid. Tydskrif vir Bedryfsielkunde, 27 (1), 25-31.

Probst, T. M. (2000). Wedded to the job: Moderating effects of job involvement on the consequences of job insecurity. Journal of Occupational Health Psychology, 5:63-73.

Robbins, S. P. (2001).Organisational Behaviour. (9th ed.). Upper Saddle River NY: Prentice Hall International Inc.

Rosenblatt, Z. \& Ruvio, A. (1996). A test of a multidimensional model of job insecurity: The case of Israeli teachers. Journal of Occupational Behavior, 17, 587-605.

Rosenblatt, Z., Talmud, I. \& Ruvio, A. (1999). A gender based framework for the experience of job insecurity and its effects on work attitudes. European Journal of Work and Organizational Psychology, 8 (2), 197 - 217.

Salter, K.M. (1999). Job insecurity and its antecedents. The Science and Engineering, 58 (2), 6508.

Scheier, M.F. \& Carver, C.S. (1985). Optimism, coping and health: Assessment and implications of generalised outcome expectancies. Health Psychology, 4, 219 - 247.

Scheier, M. F., Carver, C. S. \& Bridges, M. W. (1994). Distinguish-ing optimism from neuroticism (and trait anxiety, self- mastery, and self-esteem): A re-evaluation of the Life Orientation Test. Journal of Personality and Social Psychology, 67, 1063-1078.

Shaughnessy, J. J. \& Zechmeister, E. B. (1997). Research methods in psychology (4th ed.). NY: Mc Graw-Hill.

Spector, P. E. (1988). Development of the work locus of control scale. Journal of Occupational Psychology, 6, 335-340.

Sverke, M. \& Hellgren, J. (2002). The nature of job insecurity: Understanding Employment Uncertainty on the Brink of a New Millenium. Applied Psychology: An International Review, $51,23-52$.

Sverke, M., Hellgren, J. \& Näswall, K. (2002). No security: a metaanalysis and review of job insecurity and its consequences. Journal of Occupational Health Psychology, 7, 242-264.

Van Vuuren, T. (1990). Met ontslag bedreigd. Werknemers in onzekerheid over hun arbeidsplaats bij veranderingen in de organisatie. Amsterdam: VU Uitgeverij.

Van Vuuren, T., Klandermans, B., Jacobson, D. \& Hartley, J. (1991). Predicting employees' perceptions of job insecurity. In J Hartley, D Jacobson, B Klandermans, \& T Van Vuuren. Job insecurity: Coping with jobs at risk (pp. 65 - 78). London: Sage Publications.

Wisniewski, M. (1997). Quantitative methods for decisions-makers. England: Pitman.

Wrosch, C. \& Scheier, M. F. (2003). Personality and quality of life: The importance of optimism and goal adjustment. Quality of Life Research, 12 (1), 59 - 72. 